\title{
Assessing the Impact of Moodle LMS for Teaching Scientific English at Khartoum University on Home Science Student``Attitudes towards Learning English Language
}

\author{
Dr. Ameera Musa Ali \\ Assistant Prof. of ELT \\ Kingdom University \\ Bahrain \\ Dr. Alajab Mohammed Alajab \\ Associate Prof. of Instructional Technology \\ Arabian Gulf University \\ Bahrain
}

\begin{abstract}
The present study aimed at investigating attitudes of home science students at Khartoum University toward using the MOODLE Learning Management $\underline{S}$ ystem as electronic resource in teaching English for Science. English for Science is an 8 hour university required curriculum taught to all university science students. A group of 39 students registered for their first university required courses in the second semester of the university year 2012/2013 in the Faculty of Education were asked to assess their skills and attitudes, before using Moodle as an open source learning management system, internet- based resources in learning English for Scientific \& Academic Purposes and after 14 weeks experience. The results show that participants have positive towards using technology for learning English language; moreover the teaching methodology which integrates face-to-face teaching and Moodle Environments have positive impacts on changing participants attitudes towards using technology for teaching English at Khartoum University. The study concluded that using and integrating virtual learning environments will accelerate the educational process and enhance better affective learning outcomes.
\end{abstract}

Keywords: Attitudes toward English language, Moodle LMS, Open Source Software, and Online Learning.

\section{Introduction}

This study aims to explore the impact of utilizing a proposed blended learning strategy based on Moodle LMS for teaching scientific English at Khartoum University on home science students' attitudes towards learning English. Khartoum University is a multi-campus, co-educational, public university located in Khartoum, the capital of Sudan. It is the largest and oldest university in the country. The roots of University of Khartoum (U of K) go back to 1898 when Lord Kitchener of Khartoum proposed founding a college in memory of General Gordon (University of Khartoum web site; 2013) [1]. It was founded as Gordon Memorial College in 1902 and established in 1956 when Sudan gained independence. Since that date, the University of Khartoum has been recognized as a top university and a high-ranked academic institution in Sudan and Africa (Akec, 2009) [2].

The face to face activities of the study took place at the main branch of the educational campus located in Omdurman, the second city in Sudan and administrated by the English Language Department affiliated to the Administration of University Requirements (AUR). Khartoum University AUR was founded in 1998 and developed naturally to teach scientific subjects that known to be important among educators. The administration is responsible for teaching the university requirements subjects for first and second year students (375 hours) including Arabic Language, English Language, Islamic Culture, Computer Science and Sudanese studies (AUR, 2013) [3].

Any university student is required to study a total of 90 hours of English in the first and second year. The English for Science University Requirement is taught to all science students at the faculty of education i.e., (Faculty of education students who study mathematics, physics, biology, chemistry and home science department). 
The activities of the present study are limited to home sciences students by adopting a blended learning strategy, in which $50 \%$ of the course time was used for face-to-face classes, and the other $50 \%$ was allocated for the online learning by the use of Moodle LMS and selected internet resources in the English language. Blended Learning used in this study is a mix of traditional instructor-led training; synchronous online conferencing or training, asynchronous self-paced study, and structured on-the-job training from an experienced worker or mentor (see Singh, 2003) [4]. The face-to- face component of the study took place in Khartoum University's educational campus at the Faculty of Education Khartoum University with the hope of enhancing English Language education outcomes by improving science students' attitudes towards the English language.

Since positive attitudes of learners towards a teaching material enhance the effectiveness of that material, it is important to determine the attitudes of learners towards the material used. Basal et. al. (2012) [5] conducted a study aimed to determine the attitudes of students towards learning objects in web-based language learning. The study was conducted in English (I) Course at the Department of Computer Programming in Kirikkale University in 2010-2011 Fall Semesters. Seventy LOs appropriate for six-weeks long lecture program was integrated into the Learning Management System (LMS) of Kirikkale University on a sample of 38 students. After the six weeks long implementation period of the study, an attitude scale was administered to the students. The findings indicated that students in web based language education have positive attitudes towards LOs.

In (2012) Thang \& Bidmeshki [6], investigate the perceptions of Malaysian undergraduates of the Faculty of Science and Technology, University Kebangsaan Malaysia (UKM) towards online English for science and technology course in terms of their improvement in reading skills and strategies, their autonomy and their motivation. The required data was gathered in three phases; with phase one being implemented when the students were in the first semester. The methods applied in this phase for gathering data on the perception of the students were: (i) monitoring logging-in days and times; (ii) initiating online discussion via an online forum and; (iii) administrating online questionnaires. The findings of the study revealed that the students perceived this course as contributing highly towards their improvements in reading skills and strategies, contributing moderately towards improving their autonomy, as some of them did not desire full autonomy in that they still indicated a preference for a combination of both face-to-face and online modes of learning and contributing highly towards their motivation.

To investigate the students' experiments of using blogs to encourage them to do pre-class reading assignment and reflections after class, Al-Fadda \& Al-Yahya (2010) [7] conducted two studies on a sample included five ESL (English as a Second Language) graduate students in a course of teaching methods, and 90 software engineering students in an undergraduate information technology program. Results indicated that there was a positive attitude towards the use of blogs for pre-class preparation and post-class reflections. However, considering the successful experience, it is important to consider the class size, students' educational level, and the type of reading assignment.

As an attitudinal component, motivation has been recognized by both psychologists and educators as a key element for a successful learning outcome. In research on motivation in language learning, it is customary to view the construct as a dyadic unity of integrative and instrumental motivation. The former includes the learners' attitudes towards the culture and native speakers of the target language. Nikitina \& Furuoka (2006) [8] conducted a study aimed to explore whether integrative motivation is ubiquitous in the foreign language classroom. Contextual analysis of the open-ended questionnaires was carried out to examine perceptions that students learning Russian at University Malaysia Sabah (UMS) have about Russia, its culture and people. Results revealed, initially, only scant traces of integrative motivation were detected. However, in the course of the language program, "integrative" drive intensified. The paper proceeds to discuss whether and how pedagogical intervention might alter the learners' motivational pattern.

\section{Blended Learning and Attitudes Towards Learning Scientific English}

According to the Longman Dictionary of Applied Linguistics, 1992, "language attitudes" is defined as follows: the attitude which English speakers has towards the English language, whether positive or negative feelings. Attitudes towards a language may also show what people feel about the speakers of that language (Cited in: Karahan, 2007) [9]. 
It is very important to assess and deal with students' attitudes towards studying Scientific English. Different aspects of language attitudes have also been studied such as the relationship between attitudes and learning strategies studied by Gan, 2004, and the relationship between attitudes and achievement studied by Graham, 2004 (Cited in: Karahan, 2007)[9].

The importance of attitude is due to the effect it may have on the student's achievement, as the results of many studies have shown. Echavez-Solano (2003) [10] emphasized this by stating that positive attitude leads to an enthusiasm to study and learn English. Attitudes can possibly affect learners' achievement and the desire to continue studying in the target language. Suleiman (1993)[11] reviewed several studies such as these by Oller, Hudson and Liu, Chilhara and Oller, 1978, Gilsan, 1987, and concluded that students' achievement in English as a second language is related to their attitude toward English.

According to Brown, 1987, many factors affect students' attitude toward English. These include parents' and peers' attitude toward English; contact with English speakers and their experiences; unpleasant experiences with English speakers; and cultural attitude (Cited in: Suleiman, 1993) [11]. Students should be aware of the importance of the English language especially that the goal is not only to gain high marks in class, but also to use the language and communicate effectively (Al-Nafisah, 2001) [12]. This was the rational for including this dimension in the attitude scale used in this study.

Another dimension of this instrument is the students' motivation toward studying English. According to Gardner (1985: 10), "motivation ... refers to the combination of effort plus desire to achieve the goal of learning the language plus favorable attitudes toward learning the language." There is a strong relationship between the students' motivation to learn English and their attitude toward English. Suleiman (1993) [11] stated that some Arab students lack motivation to learn English as a foreign language and this produces an unfavorable attitude toward learning English.

Using blended learning based on Moodle VLE and its related tools can improve students' attitudes toward studying English. Liu et al. (2002)[13] argued that; using technology improves students' attitudes toward learning vocabulary citing the Ritter (1993) study where $92 \%$ of students preferred learning new vocabulary using a computer program because it reduced the students' anxiety in regards to learning a foreign language. Different studies have been done about the effect of VLE on students' attitude toward foreign language. Iddings, Ortmann \& Pride's study (1999) showed that there was a significant growth in vocabulary development for students due to the use of technology in teaching vocabulary.

Some research results indicated that there were also improvement in students' attitudes toward reading, comprehension and their overall vocabulary acquisition. Ushida (2003) [14] found that students' attitudes toward studying a foreign language through an online course were relatively positive. But the Yushau's (n.d.)[15] study, which examined the influence of blended e-learning on students' attitude towards mathematics and computers, using a random sample of 70 students of the preparatory year program of King Fahd University of Petroleum and Minerals, indicated that there was no statistically significant change in students' attitudes towards the course they studied through WebCT.

\subsection{The research problem:}

The undergraduate science students of Faculty of education at Khartoum University study compulsory English for science course as part of the foreign language policy of Sudan's Ministry of Higher Education and this is known as university required English program, taught at all Sudanese universities and Higher Education Institutions. The course aims to help the participants learn and use English language as it is the medium of instruction of the university. Due to power learning resources and large class size English instructors suffer a lot in helping their students to learn and master the course's objectives and resulted in low motivation and negative attitudes towards university required English courses as well as fears of not passing this course which sought to be studied and completed by any college student within his first 3 semesters of college education. As an effect by the authors funded by Khartoum University, the study develops a blended learning interactive environment based on Khartoum University Moodle LMS (learning Management System) for teaching the course with the hope that the proposed material will motivate the students, facilitate their learning, and give them an opportunity to practice learning English for science to the degree that removes their fears and tests anxiety related to English required courses. 
Language educators believe that subjects interest, aptitude and motivation for learning English and the chances of success in foreign language policy and medium of instruction policy implementation depend to a large extent on the favorable attitudes towards the English language.

Results of an extensive literature survey suggest that the effects of teaching methods and approaches on science students' attitude towards English for Science University Required Courses at Khartoum University have not been studied before. Therefore the present study is intended to investigate the impact of using Moodle LMS as a proposed electronic environment for teaching and studying English on home science students at the faculty of education`s attitudes towards English language. The study thought to answer the following questions; What are the home science first year students who are studying at Khartoum University demographic information like?

1. What is the English for Science University Required Course like?

2. What are the main components of the proposed teaching and learning strategy based on Khartoum University Moodle Learning environment?

3. What's the impact of the proposed treatment on subjects' attitudes towards learning and studying English Language?

\subsection{Purpose of the study:}

In the language education and media utilization, attitudes have been investigated as a qualitative component of the learning outcomes. The findings of different attitudes studies state that media utilization can enhance college students' attitudes towards learning. The purpose of the present study was to investigate the impact of using Moodle LMS on home science students who are studying English for Science University required course attitudes towards learning and studying English. In this treatment Moodle learning management system was used to deliver the course content and facilitate the participants' interactions with the learning resources and materials. The study also aimed to convert the English for Science learning material taught for home science students at the faculty of education into a self learning material based on the learning devices driven from the different learning schools of learning, and delivered via Khartoum University Moodle LMS so as to help the students learn the material and facilitate their mastery of the course objectives.

\subsection{The importance of the study:}

The importance of the present study can be seen from the following considerations:

1. It's hoped that using Moodle LMS for teaching English for Science at Khartoum University will enhance science students' attitudes towards learning English, raise their motivation to effectively communicate in the course.

2. It's hoped that home science students' experience in Moodle LMS in this study will improve as well as their instructors will encourage other faculties at Khartoum University to use Moodle LMS services for supporting their students' learning and enriching their course material.

3. The results of this study is hoped to encourage the Sudanese Higher Education planners and administrator to rethink the delivery method by recommending the use of Open Source LMS like Moodle for better teaching outcomes and low cost learning resources.

\subsection{Limitation of the study:}

The activities of the present study took place at Khartoum University, the oldest higher education institution in Sudan. Compared to other Sudanese higher education institutions; Khartoum University processes plenty of educational facilities and learning resources and it runs its mission for more than 100 years, on teaching English for scientific and Academic course to university's fresh students who study Home Science and Human Nutrition at Faculty of Education. Generalization of results will be limited to educational societies and institutions with similar learning context to Khartoum University.

\subsection{Definition of terms:}

1.5.1 Attitudes toward English language: attitudes are feelings or emotions towards a fact or state. An attitude is "a relatively enduring organization of beliefs, feelings, and behavioral tendencies towards socially significant objects, groups, events or symbols" (Hogg, \& Vaughan 2005, p. 150) [15]. For the purpose of this study, attitude was defined as the composite score on a 32-item Likert type scale develop for assessing Khartoum University home science students' attitudes towards the English language. 
1.5.2 Moodle - open-source software: Moodle is a Course Management System (CMS), also known as a Learning Management System (LMS) or a Virtual Learning Environment (VLE). It is a free web application that educators can use to create effective online learning sites (moodle.org, 2013) [16].

1.5.3 Online learning: 'online learning' as '... the use of the Internet to access learning material; to interact with the content, instructor and other learners; and to obtain support during the learning process, in order to acquire knowledge, to construct personal meaning, and to grow from the learning experience ( Anderson \& Elloumi, 2004) [17].

\section{Review of Literature}

Many studies have been conducted to explore the nature of science students' attitudes towards learning English as a second and foreign language all over the world. For example In Japan; an advisory committee nominated by the late Prime Minister Keizo Obuchi in 1999 made a proposal for the vision of the 21 st century of Japan. It stressed the importance of enhancing communicative competence in English for the Japanese to survive in international competition and to be a good member of the international community. In the light of the work of the above committee, this study investigates attitudes towards English among students in higher education in Japan (B. E. Lafaye \& S. Tsuda, 2003) [18]. Empirical data have been drawn from a survey of over 500 Japanese university students. The results indicate that students in this limited study share some fundamentally similar ideas about English, including their perceptions of their English learning experience, to which they responded negatively, and their opinions about the usefulness of English, a question to which they responded overwhelmingly in the positive. The findings seem to open up some serious pedagogical questions, and the paper thus concludes with a discussion of these and language education and policy in Japan.

Gülşen and his colleagues (2009) [19], investigated the attitudes of undergraduate students' towards English language, and showed whether there are any significant meanings among their gender, nationality and the departments which they study in. To gather information a scale is developed by researchers. The scale used to measure the attitudes towards English (reliability: 0.91) and a personal information form. The views and advice of experts were given to the validity of the used scale. Together with this, the students who participated were from the Near East University, from the departments of CEIT (Computer Education and Information Technologies) and Nursing $(\mathrm{N}=161)$. Data t-test results reveal no significant meaning between the students`attitudes towards English in regarding their gender, nationality and the departments which they study in.

In Libya; Abidin, Pour-Mohammadi \& Alzwari (2012) [20]; investigated Libyan secondary school students' attitudes towards learning English in terms of the behavioural, cognitive and emotional aspects. They also explored whether there is any significant difference in the students' attitudes towards English language based on their demographic profiles i.e., Gender, field and year of study. A total of 180 participants in the three study years from three specializations of Basic Sciences, Life Sciences, and Social Sciences took a questionnaire as a measuring instrument. Regarding the three aspects of attitude i.e., Cognitive, behavioural, and emotional, the participants showed negative attitudes towards learning English. On the demographic profile, there were statistically significant attitudinal differences regarding gender and field of study but not year of study. Based on the research findings, some recommendations are finally presented.

In UAE Omar (2013) [21]; outlines the results of a survey that was carried out, to identify Applied Technology High School students' attitudes towards learning the English language and to investigate whether the students' attitude is affected by the teacher's nativity. The study sample consisted of 196 students at the Applied Technology High School (ATHS). A questionnaire was used for data collection. The findings showed that the vast majority of the subjects of the study had positive attitudes towards learning the English Language. In addition to that; the findings revealed that teacher's nativity (native speaker vs. non native speaker of English) did not influence the students' positive orientation to the English language.

\section{Developing and Installing Course Learning Material}

The electronic component of the course was developed based on Moodle LMS used at Khartoum University. Activities of the development were guided by the principles of learning driven from teaching schools (behaviourism, cognitive theory, constructivism and social learning theory guidelines). The development process was guided by ADDIE model. ADDIE is a five phases (Analysis, Design, Development, Implement, and Evaluate) model, and of the ISD family (Instructional System Design). 
Though many of the people who work in the field think that the ADDIE model has no author, Watson (1981) [22], mentioned that: the model appears for the first time in 1975. It was created by the Centre for Educational Technology at Florida State University for the U.S. Army and then quickly adopted by all the U.S. Armed Forces. The military, having a large number of instructional designers, greatly influenced much of the corporate and educational world to adapting the ISD or ADDIE model. In the present study the phases of the model utilized are as follows:

\subsection{Analysis phase:}

In this phase the study dealt with the target group description (home science students at the faculty of education University of Khartoum who are studying the English for science university required course), where exits course outlines and description was revised, gaps were identified, learning context (class environment), and all factors related to where learning will take place was also accomplished. The product of this phase is the foundation for all subsequent design and development activities of the proposed course environment.

\subsection{Design Phase:}

The processes of this phase are driven by the products of the analysis phase and ends in a model or blueprint of the English for Science course material. During this phase, learning tasks were analyzed, learning objectives for the course were stated, the assessment instruments were developed, the proposed instructional strategy is outlined and the delivery method which is based on blended learning through Moodle LMS environment is also developed and planned.

\subsection{Development phase:}

Development is simply diagramming and outlining the necessary activities that will assist the learners in reaching the course's goals. The end result is the completed instructional courseware (workbook in English for scientific, its power point presentation-ppt, the activity book (both printed and electronic versions) as well as the Moodle environment component. The processes of this phase are driven by the products of the design phase and end in a complete course package of instructional material for teaching the English for Science University required course and hosed on Khartoum University Moodle learning Environment.

\subsection{Implementation phase.}

The initial phases of the English for Science implementation methodology which has been discussed are Analyze, Design, and Develop the course objectives and instructional requirements so that all the needed learning resources represented in (software \& hardware) are prepared to install the new products and integrate it into Khartoum University Moodle LMS to be delivered in a blended learning format. In this phase the course instructor (the first author) was prepared and trained on how to teach though Moodle environment, the electronic component of the instructional system was installed, f2f instruction component was implemented at the Educational campus for 2 contact hours a week and starting since the $17^{\text {th }}$ of October 2013 for 16 weeks i.e. (closed on $17^{\text {th }}$ April 2014). The proposed blended learning strategy was also implemented. The course meets at the Mathematics Department Computer Lab for two hours a week, for practicing online learning activities i.e. (listing to multimedia material, reading on related topics, navigating through the course material, download or upload course material, and doing extra exercise).

\subsection{Evaluation phase.}

The activities of this phase are mainly concentrated on the evaluation of the development process as well as the effect of the proposed treatment on subjects learning outcomes. The evaluation phase consists of two parts: formative and summative. For the purpose of this study, during the evaluation phase and after 2 weeks of teaching, the study administrated an attitude towards English language survey so as to assess the impact of the proposed course material on subjects learning outcomes. Learning outcomes in this study was only limited to attitudes towards English language which was tested by attitude towards the English language. The outcomes of evaluating the impact of the proposed treatment on home science attitudes towards learning \& studying English will be presented in the results section of the study.

\section{Methods \& Procedures}

The study used an experimental research method with a quasi-research design to achieve its purpose on a sample of thirty nine students studying English for Science University required courses during the second semester of the academic year 2012/2013 at the Home Science Department, Faculty of Education- University of Khartoum. 
It is worth mentioning that; the design of this piece of research is a quasi- experimental one because subjects were not assigned to study in random. It is a single - group design that was created in order to enable assessing the impact of using Moodle LMS (proposed treatment) on home science students' attitude towards learning and studying English language (outcome) after an intervention of around 14 contacts hours of teaching (14 weeks).

\subsection{Attitude towards English Language Scale}

The aim of the instrument is to collect the needed data for assessing the impact of the proposed teaching strategy (based on blending Moodle LMS into face-face class delivery) on participants (home science students at the Faculty of Education studying English for Science course) attitude towards studying and learning English. The five-point Likert scale was used to measure students' responses. The levels of the scale responses varied were strongly agree, agree, undecided, disagree and strongly disagree. Scores from 5 to 1 were assigned for positive responses and from 1 to 5 for the negative responses.

The scale was adapted from the instrument developed by Abeer (2008) [23] used to test the effect of a blended learning strategy based on WebCT LMS on Arabian Gulf University Pre-medical students' attitudes towards English Language. It is worth mentioning that; the items of the scale and statements were distributed among four sub- dimensions that form attitudes towards learning and studying English language as follows: The students' attitude towards learning English for Science (EFS) which measures the students' feelings towards English Language University required courses, classes and people.

1. The importance of learning English language; which measure \& measures the students' evaluation of the importance of English in their personal life, study and to their country.

2. Motivation towards studying English which measures the students' personal and academic reasons and motives for studying English and;

3. Fears and worries concerning studying and practicing English which measures the students' personal and academic fears concerning studying and practicing English.

Table 1: shows the distribution of attitudes statements on the sub-dimensions including;

Table (1): Distribution of the attitude statements on the Sub-dimensions

\begin{tabular}{l|l|l}
\hline & Scale sub-dimension & Items/ statements \\
\hline $1 .$. & The attitude toward learning English language & $1,8,14,16,22,25,30$ \\
\hline 2. & The importance of learning English & $3,7,9,15,20,23,26,28,29,31$ \\
\hline 3. & Motivation toward studying English & $2,4,6,10,13,18$ \\
\hline 4. & Fears and worries concerning studying and practicing English & $5,11,12,17,19,21,24,27,32$. \\
\hline
\end{tabular}

The attitude towards English language was composed of 32 statements distributed among the four dimensions build up the study scale: The attitude toward learning English language (7 statements), the importance of learning English (10 statements), motivation toward studying English (6 statements) and fears and worries concerning studying and practicing English (9 statements). The computed value of Cronbach's Alpha for the whole scale found to be (.769) Table 2 . Shows the scale reality statistic results.

Table 2: Attitudes towards English Language Reliability Statistics

\begin{tabular}{|l|l|l|}
\hline Cronbach's Alpha & Cronbach's Alpha Based on Standardized Items & N of Items \\
\hline .769 & .798 & 32 \\
\hline
\end{tabular}

Inter-items correction coefficient was computed and found to be of significance at 0.01 levels. Table (3) shows the inter-item correlation matrix for the whole scale and its-sub-dimensions. 
Table 3: inter-item correlation matrix for the attitude towards English Scale and its-sub-dimensions

\begin{tabular}{|c|c|c|c|c|c|c|}
\hline & & $\begin{array}{l}\text { Whole } \\
\text { Scale }\end{array}$ & $\begin{array}{l}\text { Attitude } \\
\text { toward } \\
\text { learning } \\
\text { English } \\
\text { language }\end{array}$ & $\begin{array}{l}\text { Importance of } \\
\text { learning } \\
\text { English }\end{array}$ & $\begin{array}{l}\text { Motivation } \\
\text { toward } \\
\text { studying } \\
\text { English }\end{array}$ & $\begin{array}{l}\text { Fears \& worries } \\
\text { of studying and } \\
\text { practicing } \\
\text { English }\end{array}$ \\
\hline \multirow[t]{3}{*}{ Whole Scale } & $\begin{array}{l}\text { Pearson } \\
\text { Correlation }\end{array}$ & 1 & $.695^{* *}$ & $.586^{* *}$ & $.737^{* *}$ & $.799^{* *}$ \\
\hline & $\begin{array}{ll}\begin{array}{l}\text { Sig. } \\
\text { tailed })\end{array} & (2- \\
\end{array}$ & & .000 & .000 & .000 & .000 \\
\hline & $\mathrm{N}$ & 39 & 39 & 39 & 39 & 39 \\
\hline \multirow{3}{*}{$\begin{array}{lr}\text { Attitude } & \text { toward } \\
\text { learning } & \text { English } \\
\text { language } & \end{array}$} & $\begin{array}{l}\text { Pearson } \\
\text { Correlation }\end{array}$ & $.695^{* *}$ & 1 & .034 & $.511^{* *}$ & $.545^{* *}$ \\
\hline & $\begin{array}{ll}\begin{array}{l}\text { Sig. } \\
\text { tailed })\end{array} & \text { (2- }\end{array}$ & .000 & & .837 & .001 & .000 \\
\hline & $\mathrm{N}$ & 39 & 39 & 39 & 39 & 39 \\
\hline \multirow[t]{3}{*}{$\begin{array}{l}\text { Importance of } \\
\text { learning English }\end{array}$} & $\begin{array}{l}\text { Pearson } \\
\text { Correlation }\end{array}$ & $.586^{* *}$ & .034 & 1 & $.381^{*}$ & .196 \\
\hline & $\begin{array}{ll}\begin{array}{l}\text { Sig. } \\
\text { tailed })\end{array} & (2- \\
\end{array}$ & .000 & .837 & & .017 & .231 \\
\hline & $\mathrm{N}$ & 39 & 39 & 39 & 39 & 39 \\
\hline \multirow{3}{*}{$\begin{array}{l}\text { Motivation } \\
\text { toward studying } \\
\text { English }\end{array}$} & $\begin{array}{l}\text { Pearson } \\
\text { Correlation } \\
\end{array}$ & $.737^{* *}$ & $.511^{* *}$ & $.381^{*}$ & 1 & $.356^{*}$ \\
\hline & $\begin{array}{ll}\text { Sig. } \\
\text { tailed) }\end{array}$ & .000 & .001 & .017 & & .026 \\
\hline & $\mathrm{N}$ & 39 & 39 & 39 & 39 & 39 \\
\hline \multirow{3}{*}{$\begin{array}{l}\text { Fears \& worries } \\
\text { of studying and } \\
\text { practicing } \\
\text { English }\end{array}$} & $\begin{array}{l}\text { Pearson } \\
\text { Correlation }\end{array}$ & $.799^{* * *}$ & $.545^{* *}$ & .196 & $.356^{*}$ & 1 \\
\hline & $\begin{array}{l}\text { Sig. } \\
\text { tailed })\end{array}$ & .000 & .000 & .231 & .026 & \\
\hline & $\mathrm{N}$ & 39 & 39 & 39 & 39 & 39 \\
\hline
\end{tabular}

\subsection{Procedures}

The study was conducted during the second semester of the academic year 2012/2013 at the Faculty of Education, Khartoum University. Before the start of the semester the study material was developed and revised by the first author who is a lecturer in English language, and the second author who is an associate professor in instructional systems design and distance education.

\subsection{Data analysis}

Subjects' responses on the attitudes towards learning and studying English data were coded numerically and entered on an SPSS version 19 database. Paired sample t-test was used to determine the effect of the proposed treatment on participants' attitudes towards English language. Descriptive analysis was utilized to compare the means and standard deviations for pre and post attitudes survey in all sub-domains and the items of the scale.

\section{Results \& Discussions}

In the following sections the results of the study will be tabled and discussed. The results include a description of demographic information of the participants (home science students who were studying the English for science university required course) then following by discussing aims, outlines, objective and topics of the English for science course, the systematic development of the course Moodle environment component, and closed by the effect of proposed treatment on subjects' attitudes towards English results. 


\subsection{Results related to subject demographic data}

The participants of the study were 39 college students. There were one male $(2.6 \%)$ and $38(97.4 \%)$ female students. Their age varied from 17 to 21 years old and the reported mean value was 18.69 (S.D. = 1.6013). Concerning their Sudanese high school certificate, their scores ranged between 95 and 56, with an average of (74.48), and SD (1.06). Their first semester GPA mean is $(\mathrm{m}=2.57, \mathrm{SD}=.481)$ and ranged between 1.58 and 3.39. Concerning their experience in computer \& internet, around $30.8 \%$ (12) classified themselves at week experience level, 59.0\% (23) possessed an intermediate level of experience in computer and internet. Table (4) shows the students demographic and experiential characteristics.

Table 4: Characteristics of the students`group

\begin{tabular}{|l|l|l|}
\hline Variable & Frequency & $\%$ \\
\hline Gender & 1 & \\
Male & 38 & 2.6 \\
Female & & 97.4 \\
\hline Age & & 18.69 \\
Mean & & 01.60 \\
Std. Deviation & 21.00 \\
Maximum & & 17.00 \\
Minimum & & \\
\hline Score in Secondary English & 74.49 \\
Mean & & 9.06 \\
Std. Deviation & 95 \\
Maximum & & 56 \\
Minimum & & \\
\hline GPA & & 2.57 \\
Mean & & .481 \\
Std. Deviation & 3.39 \\
Maximum & 23 & 1.58 \\
Minimum & 4 & 30.8 \\
\hline Internet \&computer experience & 59.0 \\
Week exp. & & 10.3 \\
Intermediate exp. & \\
Advance expense. & & \\
\hline
\end{tabular}

\subsection{What English for Science University required course like?}

English for science is a university required courses and was launched under the authority of the administration of the university requirements unit (ARU). During English program, students are required to study a total of 90 hours of English in the first and second year of their Bachelor program. With the depressed current situation of English in the general education system, the poor teaching environment and many obstacles at the University of Khartoum, colleges may graduate students with very poor levels of English language achievement who are unable to compete for jobs.

According to (ARU) the general objectives of the English curriculum are stated as follows (1) to develop the students' language skills: reading, writing, listening and speaking, (2) to enhance language sub-skills, and (3) to raise students' awareness to the importance of the English language as a language of science and technology. Concerning English for Science or English for Specific /Academic Purposes (ESP/ EAP), it's a university required course oriented towards the student's specialization. The objectives of the course are that by the end of the course students should be able to:

1. Read with understanding scientific texts related to their field of study.

2. Acquire terminology related to their field of specialization.

3. Apply the scientific style in their writing.

4. Analyze texts to their linguistic elements.

5.Use correct grammar when writing.

6. Write scientific and academic essays. 
7.Write a correct list of references.

8.Use references appropriately: citation, summary, quotation, and paraphrasing.

9. Take notes from references and lectures.

10. Write their CV correctly.

11. Write job application letters in the correct style.

12. Write and present seminar paper.

In general, the course contains three parts:

a) Reading texts: these texts are content- based. They are driven from students' field of study. They are selected by the curriculum committee.

b) Grammar and Structure: this section is related to the reading section to provide grammar in context. The grammar in focus is taken from the texts provided in the reading section. In addition, the following points are also taught: Relative clause, Sentence structure. Sentence types, Phrasal verbs, Passive voice, Articles, Direct and indirect speech.

c) Writing: this part is a continuation to the writing part in the first year textbook. The writing is mainly academic. It covers the following points:

$\checkmark$ Scientific essay writing.

$\checkmark$ Reference writing.

$\checkmark$ Summary writing.

$\checkmark$ Paraphrasing.

$\checkmark$ Note-taking.

$\checkmark$ Scientific and Report writing.

$\checkmark \mathrm{CV}$ writing.

$\checkmark$ Job application letter writing.

$\checkmark$ Presenting and writing seminar paper.

The department of English is teaching the following courses:[1] English for Law (Faculty of Law), [2] English for Medical Studies (Faculties of Medicine, Pharmacy Dentistry), [3] English for Nursing Faculty of Nursing), [4] English for Environmental Studies (Faculty of Health and Hygiene),[5] English for Economics (Faculty of Economics), [6]English for Engineering (Faculty of Engineering), [7] English for Architecture (Faculty of Architecture), [8] English for Computer (Faculty of Mathematical Sciences),[9] English for Laboratory (Faculty of Laboratory Sciences),[10] English for Business (Faculty of Business Administration), [11]English for Geology (Faculty of Science),[12]English for Math and Chemistry (Faculty of Science),[13] English for Biology (Faculty of Science),[14]English for Arts (Faculty of Education),[15] English for Science (Faculty of Education),[16] English for Physical Education (Faculty of Education), [17]English for Arts (Faculty of Education- Basic Level),[18] English for Science (Faculty of Education- Basic Level), [19]English for Animal Production and Veterinary Studies (Faculties of Animal Production and Veterinary Medicine), and [20] English for Agriculture and Forestry (Faculties of Agriculture and Forestry).

\subsection{What are the components and format of the proposed English for Science University required courses?}

The activities of the present study are limited to English for Science taught at Faculty of education for the home science students seeking specialized in human nutrition. The goal of the study was to redesign the course topics and develop learning material that helps home science candidates to master the course objectives stated by the Khartoum University Requirement Unit.

\subsubsection{Course Objectives:}

The general aim of the Scientific English University Requirement Course (SEURC) is to upgrade the overall English language proficiency of students entering the home science \& biological sciences programs from a lowintermediate to intermediate level. A major objective of this course is to involve students in communicative interaction in English in order to increase their confidence and ability to deal with the demands placed on their skills in an integrated way in the language class.

\subsubsection{Course Outline:}

The English for Science skills practice include the following components: 
1. Structure (Grammar): Review of those structures and functions frequently encountered in scientific discourse, particularly those related to describing, defining, comparison and contrast, classification and process.

2. Reading: Improving general reading skills of anticipation, prediction, skimming, scanning, understanding main ideas, vocabulary in context, increasing reading speed and comprehension, particularly of scientific texts and using a scientific dictionary.

3. Writing: Focus on developing paragraph writing skills; developing fluency and accuracy in writing; introduction to note-taking, paraphrasing and summary writing.

4. Vocabulary: Basic vocabulary and frequently used terms in scientific discourse, specifically those relating to human biology and anatomy; nutrition, child education, medical and family terminology.

5. Speaking: Developing oral proficiency and fluency through asking, explaining, summarizing, presenting information orally (through individual, pairs and small group activities); improving pronunciation through drilling, reading and modelling.

6. Additional English for Science Improving Activities:

- Small group discussions: Students exhibiting substantial deficiencies in any of the above skill areas will be required to undertake further practice in small group discussion setting. Small group discussion focusing on grammar, writing and further fluency practice (speaking) will be conducted several times a week.

○ Out of Class Activities : All students are required to complete an individualized program to improve their general English proficiency through self-access and/or project work as determined and agreed upon with their course instructor.

\subsubsection{The proposed teaching Strategy:}

The material of the course taught through a blended learning approach in which face -to-face sessions, printed material (course workbook), interactive computer-based learning resources, internet resources (electronic learning resources) were integrated and mixed. The blending ratio was around $50 \%$ for traditional teaching and the same ratio for e-learning which delivered via Khartoum University Moodle LMS. To access the Moodle component of the course go to the following link: http://classes.uofk.edu/, then click on educational sciences link and then the course link.

\subsection{What is the impact of the proposed blended learning strategy on Khartoum University first home science students' attitudes towards learning English for Science?}

To test the impact of the proposed teaching strategy on subjects' attitudes towards learning and studying English for Science, the attitudes towards English language was administrated at the beginning of the course (the $2^{\text {nd }}$ week) and the end of the course $\left(16^{\text {th }}\right.$ week of the semester) using the proposed material and blended learning strategy. The attitudes towards English language instrument were answered by 39 candidates of the course participants who were 46 in total. As stated earlier the attitude instrument was composed of 32 items distributed among 4 sub-domains that build subjects' attitudes towards the English language. Table ( 5 \&6) show mean scores, standard deviations with regard to subjects` pre and post attitudes towards English language for attitudes dominion and the scale as the whole respectively.

Table (5): Mean scores, standards deviations \& degree of judge with regard to pre -attitudes towards English

\begin{tabular}{|l|l|l|l|l|}
\hline Scale dimension & $\mathrm{N}$ & Mean & Std. Deviation & Degree of Judge \\
\hline $\begin{array}{l}\text { The attitude toward learning } \\
\text { English language }\end{array}$ & 39 & 3.9853 & .47809 & Above average \\
\hline $\begin{array}{l}\text { The importance of learning } \\
\text { English }\end{array}$ & 39 & 4.3590 & .44646 & High \\
\hline $\begin{array}{l}\text { Motivation toward studying } \\
\text { English }\end{array}$ & 39 & 3.9316 & .55767 & Above average \\
\hline $\begin{array}{l}\text { Fears and worries } \\
\text { concerning studying and } \\
\text { practicing English }\end{array}$ & 39 & 3.1054 & .62123 & Above average \\
\hline The whole scale & 39 & 3.8446 & .37104 & Above average \\
\hline
\end{tabular}

From table 5, it concluded the following: 
1) Subject's attitudes towards English language in all dimensions scored a mean $(\geq 3.0)$ and judged as above average, i.e. (the four dimensions of scale means ranges from above average to high). The Importance of learning English scored the highest mean $(\mathrm{m}=4.359, \mathrm{Sd} .=.4465)$, then came the attitude toward learning English language component $(\mathrm{m}=3.9853$, Sd. =. 4780), motivation toward studying English $(\mathrm{m}=3.9316, \mathrm{Sd}$. $=.55767)$. Fears and worries concerning studying and practicing English scored the lowest mean $(\mathrm{m}=3.1054$, Sd. $=.62123)$.

2) The overall mean score of the subjects' attitudes towards English language judgment is above average $(\mathrm{m}=3.8446, \mathrm{Sd} .=.37104)$.

3) The importance of learning English reported the highest score i.e. $(\mathrm{M}=4.3590 ; \mathrm{SD}=.44646)$, which indicated that all students believe on the importance studying and learning English as a language of science and technology.

Table 6: Mean scores, standards deviations \& degree of judge with regard to post -attitudes towards English

\begin{tabular}{l|l|l|l|l}
\hline Scale dimension & N & Mean & Std. Deviation & Degree of Judge \\
$\begin{array}{l}\text { The attitude toward learning English } 39 \\
\text { language }\end{array}$ & 4.3370 & .39936 & High \\
\hline $\begin{array}{l}\text { The importance of learning English } \\
\text { Motivation toward studying English }\end{array}$ & 39 & 4.4821 & .34172 & High \\
\hline $\begin{array}{l}\text { Fears and worries concerning } \\
\text { studying and practicing English }\end{array}$ & 39 & 4.1282 & .43673 & High \\
\hline \begin{tabular}{l} 
The whole scale \\
\hline
\end{tabular}
\end{tabular}

In the post attitudes survey a noticeable enhancement in subjects' attitudes towards English language was reported. From the post attitudes towards English language survey results (table 6) one can concluded that; subjects` attitudes towards English language in all dimensions scored a mean $(\geq 4.0)$ and judged as high, i.e. (the four dimensions of scale means ranges from high and approach to very high). The Importance of learning English scored the highest mean $(\mathrm{M}=4.4821, \mathrm{Sd} .=.39936)$, then came the attitude toward learning English language component $(\mathrm{M}=4,3370, \mathrm{Sd} .=.4780)$, fears and worries concerning studying and practicing English $(\mathrm{M}=4.1339$, Sd. = .37218). Motivation toward studying English scored the lowest mean $(\mathrm{M}=4.1282$, Sd. $=.43673)$.

The overall mean score of the subjects' attitudes towards English language judgment in the post survey is high $(\mathrm{M}=4.2804, \mathrm{Sd} .=.28375)$. Table 9 summarizes subjects' means in pre and post attitudes surveys.

Table 7: The Mean and Standard Deviation of the Pre \&Post Attitude Measures

\begin{tabular}{l|l|l|l}
\hline Attitude Dimension & Survey & Mean & Std. Deviation \\
\hline \multirow{2}{*}{ The attitude toward learning English language } & Pre & 3.9853 & .47809 \\
\cline { 2 - 4 } & Post & 4.3370 & .39936 \\
\hline \multirow{2}{*}{ The importance of learning English } & Pre & 4.3590 & .44646 \\
\cline { 2 - 4 } & Post & 4.4821 & .34172 \\
\hline \multirow{2}{*}{ Motivation toward studying English } & Pre & 3.9316 & .55767 \\
\cline { 2 - 4 } & Post & 4.1282 & .43673 \\
\hline \multirow{2}{*}{$\begin{array}{l}\text { Fears and worries concerning studying and } \\
\text { practicing English }\end{array}$} & Pre & 3.1054 & .62123 \\
\cline { 2 - 4 } & Post & 4.1339 & .37218 \\
\hline \multirow{2}{*}{ The whole scale } & Pre & 3.8446 & .37104 \\
\cline { 2 - 4 } & Post & 4.2804 & .28375 \\
\hline
\end{tabular}

The results of table 7 indicate that all attitudes component post survey means exceeded their pre survey means. To test the impact of the proposed blended learning strategy for teaching English for science on subjects`attitudes toward English, a paired sample t- test was conducted to evaluate whether subjects attitudes affected by blended learning or not.

Table (8) shows paired samples (pre-post) test results with 95\% level of condense interval of the difference on subjects' attitudes towards learning and studying English. 
Table 8: Parried samples t-test results of the Pre \&Post Attitude Measures

\begin{tabular}{|c|c|c|c|c|c|c|c|c|}
\hline \multirow[t]{3}{*}{ Attitude Dimension } & \multicolumn{5}{|c|}{ Paired Differences } & \multirow[t]{3}{*}{$\mathrm{t}$} & \multirow[t]{3}{*}{$\mathrm{df}$} & \multirow{3}{*}{$\begin{array}{l}\text { Sig. } \\
(2- \\
\text { tailed })\end{array}$} \\
\hline & \multirow[t]{2}{*}{ Mean } & \multirow[t]{2}{*}{ SD } & \multirow[t]{2}{*}{$\begin{array}{l}\text { Std. Error } \\
\text { Mean }\end{array}$} & \multicolumn{2}{|c|}{$\begin{array}{l}95 \% \text { Confidence Interval } \\
\text { of the Difference }\end{array}$} & & & \\
\hline & & & & Lower & Upper & & & \\
\hline $\begin{array}{l}\text { The attitude toward learning } \\
\text { English language }\end{array}$ & -.35165 & .69666 & .11155 & -.57748 & -.12582 & $-\overline{3.152}$ & 38 & .003 \\
\hline $\begin{array}{l}\text { The importance of learning } \\
\text { English }\end{array}$ & -.12308 & .33518 & .05367 & -.23173 & -.01442 & $-\overline{2}-293$ & 38 & .027 \\
\hline $\begin{array}{l}\text { Motivation toward studying } \\
\text { English }\end{array}$ & -.19658 & .74817 & .11980 & -.43911 & .04595 & $-\overline{1}-641$ & 38 & .109 \\
\hline $\begin{array}{l}\text { Fears and worries } \\
\text { concerning studying \& } \\
\text { practicing English }\end{array}$ & $-\overline{1.02849}$ & .72086 & .11543 & -1.26216 & -.79482 & $\begin{array}{l}- \\
8.910\end{array}$ & 38 & .000 \\
\hline The whole scale & -.43590 & .47679 & .07635 & -.59046 & -.28134 & $-\overline{5.709}$ & 38 & .000 \\
\hline
\end{tabular}

The results (table $7 \& 8)$ indicated that subjects overall post mean of attitude towards English $(\mathrm{M}=4.2804$, SD $=.28375)$ was significantly greater than their pre mean of attitudes towards English $(\mathrm{M}=3.8446, \mathrm{SD}=.37104), \mathrm{t}$ $(38)=5.7092, \mathrm{P}<0.05$.

According to table (10) results, subjects`attitudes towards English would be high with respect to the use of the proposed blended learning strategy, the design of the online material, the learning content, and learning experience via Moodle LMS. However, the overall attitudes towards English would be above medium with respect to the use of the blended learning strategy. Also the means of attitude toward learning English language, the importance of learning English language, and Fears and worries concerning studying and practicing English were significantly larger than 3 at the (0.05) level. A notable result is that; the mean of motivation toward studying English component in the post survey $(\mathrm{M}=4.2804, \mathrm{SD}=.43673)$ is greater than it has mean in the pre survey $(\mathrm{M}=3.9316, \mathrm{SD}=.55767), \mathrm{t}(38)=1.641, \mathrm{P}<109$, not statistically significant at the (0.05) level. This indicates that the students' attitudes towards English language were positively improved by integrating Moodle LMS in teaching English for science at Khartoum University.

\subsection{Discussion}

The main goal of the present study was to assess the impact of a proposed blended learning strategy based Moodle IMS on Khartoum University first year attitudes towards scientific English. Attitudes towards learning and studying English was assessed by an attitudes instrument developed for the purpose of the study which administrated before and after the treatment. Attitudes data was analyzed by using pair sample t-test. To assess the impact of integrating Moodle LMS and face -to-face sessions for teaching English on Khartoum University students' attitudes towards English, a quasi- experimental research design was used on a sample of 39 students studying home science at Faculty of education. The blending strategy was $50 \%$ based (50\% for face-to-face sessions and 50\% for the online learning using Khartoum University Moodle LMS). For the purpose of the study the English for Science was redesigned to fit the proposed blended learning strategy. Parried samples t-test results revealed that using Moodle LMS for delivering the online components of the course material has significantly improved the home science students' attitudes towards English language. The study found that: there are statistically significant differences in subjects`attitude scale scores at level $(\mathrm{a} \leq 0.05)$ between the pre survey and the post surely in regard with the attitude aspects; attitude toward learning English language (ATLE), The importance of learning English (ILE), Motivation toward studying English (MTE), Fears and worries concerning studying and practicing English (F\&WCTE).

Data analysis related to subjects attitudes towards Scientific English results was positively supported the study main hypothesis stated that: [there are statistically significant differences between the health \& therapeutic first year students (excremental group) pre and post attitudes towards leaning English for Science survey due to the use of the proposed blended learning strategy]. Thus, the proposed blended learning strategy positively improve subjects`attitude towards learning \& studying Scientific English. Possible explanations for the non-significant result related to students' attitude toward English language are: As a result, the implementation of the proposed blended learning strategy based on Moodle online learning environment increased the students' acceptance of the 80 
online environment of the course, motivated them and enhanced their learning. Moreover, the Blended learning English for Science University required course paved and smooth the way for the students in the traditional classroom setting to participate and share their opinions with their classmates. It also allowed the students to think, interact, and improve their language skills at their own pace. This is an important point as the students enrolled in such a course learning activity related to different language skills and therefore, their attitudes towards learning and studying Scientific English language is enhanced and developed.

The current study is similar to the findings of Ushida's (2003) [14] study that indicated using online course improved students' attitudes towards learning L2. The reason for the significant development in the students' attitude in Ushida (2003)[14] study was the presence of the teacher that affected the students' scores and satisfaction with the online course material. This results supported by (Thang \& Bidmeshki, 2012) [6] who proved the positive impact of online learning in improving reading skills and strategies for science students, and AlFadda \& Al-Yahya (2010) [7] who indicated that there was a positive attitude towards the use of blogs for preclass preparation and post-class reflections.

\section{Conclusion}

After discussing the results of the present study; and concluded its findings, the authors may acknowledge that this study has a great value for the field of language education in general and for language education in Sudan in particular. The findings will add benefit to Sudanese higher educational research as well as assist Scientific English language educators in planning and developing similar blended learning programs. In conclusion, to help your students build a positive attitude towards studying and learning English language, it is a good start to design your materials based on your students' needs and make use of the available online learning resources to support your students learning and expand their language experience. Khartoum University needs to pay extra efforts and funds for successful e-learning by training the staff on how to develop e-learning materials using LMS tools for learning delivery.

\section{References}

University of Khartoum (2013). Khartoum University Historical Background. Available online @. http://www.uofk.edu/en/about/historical

Akec, John A. (14 February 2009) Why the university education still excites Sudanese? The Sudan Tribune, Comment and Analysis, Retrieved 21 August 2012

Administration of University Requirements (2013). AUR: establishment and development. Available online @ http://aur.uofk.edu/index.php?direction=ltr\&lang=en

Singh, Harvey (2003). Building Effective Blended Learning Programs. Educational Technology, Volume 43, Number 6, Pages 51-54.

Basal, Ahmet; Gurol, Mehmet; Sevindik, Tuncay (2012). Attitudes of Students towards Learning Objects in WebBased Language Learning (EJ976979). Turkish Online Journal of Distance Education, v13 n1 p238-247 Jan 2012

Thang, Siew Ming; Bidmeshki, Leila (2012). Investigating the Perceptions of UKM Undergraduates towards English for Science and Technology Online Course (EJ875351). Computer Assisted Language Learning, v23 n1 p1-20 Feb 2010.

Al-Fadda, Hind; Al-Yahya, Maha (2010). Using Web Blogs as a Tool to Encourage Pre-Class Reading, PostClass Reflections and Collaboration in Higher Education (ED511312). Online Submission, US-China Education Review v7 n7 p100-106 Jul 2010.

Nikitina, Larisa; Furuoka, Fumitaka (2006). Integrative Motivation: How Perceptions of the Target Language Country Influence Students' Motivational Pattern (ED508698). Online Submission, Paper presented at the Science and Art of Language in Teaching International Conference (Pulua Pinang, Malaysia, Nov 20, 2006).

Karahan, F. (2007). Language attitudes of Turkish students towards the English language and its use in Turkish context. Journal of Arts and Sciences, 7, 73-87

Echavez-Solano, N. (2003). A comparison of student outcomes and attitudes in technology-enhanced vs. traditional second-semester Spanish language courses. Unpublished doctoral Thesis, University of Minnesota. 
Suleiman, M. F. (1993). A Study of Arab Students Motivations and Attitudes for Learning English as a Foreign Language. Unpublished Doctoral Thesis, University of Arizona State.

Al-Nafisah, K. (2001). A study of the curriculum and methodology for the teaching of English in Saudi Arabia with particular reference to learning difficulties encountered by students. Unpublished Doctoral Thesis, University of Wales, Swansea.

Liu, M., Moore, Z., Graham, L. and Lee, S. (2002). A look at the research on computer-based technology use in second language learning: a review of literature from 1990-2000. Journal of Research on Technology in Education, 34 (3), 250-273; ProQuest Education Journals.

Ushida, E. (2003). The role of students' attitude and motivation in second language learning in online learning courses. Unpublished Doctoral Thesis, University of Carnegies Mellon, USA.

Yushau, B. (no date). The effects of blended e-learning on mathematics and computer attitudes in pre-calculus algebra. TMME; 3 (2), 176-183. Retrieved July 20, 2013 from, http://www.math.umt.edu/ TMME/ vol3no2/TMMEvol3no2_SaudiArabia_pp176_183.pdf

Hogg, M., \& Vaughan, G. (2005). Social Psychology (4th edition). London: Prentice-Hall.

Moodle.org (2013). Welcome to the Moodle community. Available online @ https:// moodle. org/

Anderson T. and Elloumi, F. (eds) (2004) Theory and Practice of Online Learning. [Download from http://cde.athabascau.ca/online_book.]

B. E. Lafaye \& S. Tsuda (2003). Attitudes towards English Language Learning in Higher Education in Japan, and the Place of English in Japanese Society. Intercultural Communication Studies .Pp 145-161.

Gülşen Hussein, Mukaddes Sakallı Demirok, \& Hüseyin Uzunboylu (2009). Undergraduate student's attitudes towards English language. Procedia - Social and Behavioural Sciences Volume 1, Issue 1, 2009, Pages 431-433.

Abidin, Mohamad Jafre Zainol; Pour-Mohammadi, Majid; Alzwari, Hanan (2012). EFL Students' Attitudes towards Learning English Language: The Case of Libyan Secondary School Students. Asian Social Science; Feb2012, Vol. 8 Issue 2, p119. Available online at: http://connection.ebscohost.com/c/articles/71974418/efl-students-attitudes-towards-learning-englishlanguage-case-libyan-secondary-school-students.

Omar Al Noursi (2013). Attitude towards Learning English: The case of the UAE Technological High School. Educational Research (ISSN: 2141-5161) Vol. 4(1) pp. 21-30, January 2013

Watson, Russell (October 1981). Instructional System Development. In a paper presented to the International Congress for Individualized Instruction. EDRS publication ED 209239.

Alshwiah, Abeer Aidh S. (2008). The effects of a blended learning strategy in teaching vocabulary on premedical students`achievement, satisfaction and attitude towards English Language: A published master thesis' submitted to fulfill the requirement of the master degree in distance teaching \& training- Arabian Gulf University. Available online at: https://files.eric.ed.gov/fulltext/ED506107.pdf 